Article

\title{
Digital Placemaking for Urban Regeneration: Identification of Historic Heritage Values in Taiwan and the Baltic States
}

\author{
Chih-ming Shih ${ }^{1}$, Sandra Treija ${ }^{2}$, Kęstutis Zaleckis ${ }^{3}$, Uǵis Bratuškins ${ }^{2}$, Chi-Hui Chen ${ }^{1}$, Yen-Hung Chen ${ }^{1}$, \\ Charles Tzu Wei Chiang ${ }^{1}$, Laura Jankauskaitè-Jurevičienè ${ }^{3}$, Jūratė Kamičaitytè ${ }^{3}$, Alisa Korololova ${ }^{2, *}$, \\ Huei-Chen Lee ${ }^{1}$, Arnis Lektauers ${ }^{4}$ and Aušra Mlinkauskienè ${ }^{3}$ \\ ${ }^{1}$ Department of Architecture, National Taiwan University of Science and Technology, Taiwan; \\ E-Mails: scm@mail.ntust.edu.tw (C.-m. S.), ccccccay@gmail.com (C.-H.C.), yh-chen@mail.ntust.edu.tw (Y.-H.C.), \\ charlechiang@gmail.com (C.T.W.C.), hueijane.lee@gmail.com (H.-C.L.) \\ ${ }^{2}$ Faculty of Architecture, Riga Technical University, Latvia; E-Mails: sandra.treija@rtu.Iv (S.T.), ugis.bratuskins@rtu.Iv (U.B.), \\ alisa.korolova@rtu.lv (A.K.) \\ ${ }^{3}$ Faculty of Civil Engineering and Architecture, Kaunas University of Technology, Lithuania; \\ E-Mails: kestutis.zaleckis@ktu.It (K.Z.), laura.jankauskaite-jureviciene@ktu.It (L.J.-J.), jurate.kamicaityte@ktu.It (J.K.), \\ ausra.mlinkauskiene@ktu.It (A.M.) \\ ${ }^{4}$ Department of Modelling and Simulation, Riga Technical University, Latvia; E-Mail: arnis.lektauers@rtu.Iv \\ * Corresponding author
}

Submitted: 29 April 2021 | Accepted: 24 June 2021 | Published: 17 November 2021

\begin{abstract}
The active use of modern technology has affected the relationship between people and place. The "digital environment" and the "digital community" are becoming an increasingly important factor in people's daily life, leading to a loss of belonging to a place, an entire neighbourhood, and a community. In the long run, this poses risks to the unification of values and the loss of identity. In this context, the involvement of the local community in the identification and preservation of historical heritage and defining the specific values of each site is particularly important. Thus, both the attraction of the local community to specific places and the revealed potential of local tourism are promoted. Digital placemaking enters urban regeneration as a logical approach to mixing digital and physical environments and involving the local community. Several GIS-based platforms and other tools are used to identify heritage values, both tangible and intangible. Although digital placemaking is emerging worldwide, its manifestations are closely related to specific local circumstances. The article focuses on the key characteristics and configurations of the digital placemaking tools within particular communities. The study tests digital placemaking practice in the historical districts of three cities: Taipei (Taiwan), Riga (Latvia), and Kaunas (Lithuania).
\end{abstract}

\section{Keywords}

Baltic states; digital placemaking; heritage values; public involvement; Taiwan; urban regeneration

Issue

This article is part of the issue "Towards Digital Urban Regeneration: Embedding Digital Technologies Into Urban Renewal Processes and Development" edited by Dalit Shach-Pinsly (Technion-Israel Institute of Technology, Israel).

(C) 2021 by the authors; licensee Cogitatio (Lisbon, Portugal). This article is licensed under a Creative Commons Attribution 4.0 International License (CC BY).

\section{Introduction}

People and place relations are playing an increasingly important role in ensuring the quality of the urban environment. At the turn of the 21st century, "in the urban design and conservation fields, despite a strong interest in people-place relationships, the emphasis in practice was on structures and forms of urban areas, with little attention to cultural values" (Stephenson, 2010 , p. 14), whereas contemporary urban regeneration 
practices focus on place identity (Boussaa, 2017; Zheng et al., 2014), involving cultural heritage in the core of regeneration strategies (Tweed \& Sutherland, 2007).

In the process of urban regeneration, the placemaking approach is used as one of the tools to form the identity of a place to determine heritage value (Sepe, 2015). The placemaking approach in this context offers ample opportunities in urban regeneration to recognise people's needs and interests as one of the driving forces of the process (Sweeney et al., 2018).

Today, digitalisation brings new opportunities in many areas. It also provides excellent opportunities for urban regeneration processes and placemaking activities. Digital placemaking is becoming an increasingly used approach in urban regeneration, providing a multifaceted exchange of information and views (de Filippi et al., 2020; Freeman et al., 2019).

This article aims to highlight approaches and tools for digital placemaking in urban regeneration in historic areas of different scales and contexts. The study focuses on key characteristics and configurations of the digital placemaking tools within particular communities in Taipei (Taiwan), Kaunas (Lithuania), and Riga (Latvia).

\section{Digital Placemaking for Urban Regeneration}

Heritage, as described by Ashworth (1997), is a term that includes almost anything that is inherited from the past and destined for the future. It refers to the outcome of the past, through the combination of three different aspects such as the process of interpretation of history, consolidation of memory, and collection of relics (Pendlebury, 2014). Heritage is defined in UNESCO documents as "our legacy from the past, what we live with today, and what we pass on to future generations" (UNESCO, 2008, p. 5). It is something that is, or should be, passed on from generation to generation because it is valued. Pendlebury and Porfyriou (2017) also explained "heritage" as the outcome of success from past urban environments that witnessed the process of transformation through time. "Urban-regeneration" is referred to by planners and designers as the enhancement of an urban situation, specifically regarding social and economic statuses. The use of "regeneration" concerning "heritage" often linked both strategies for the development of cultural industries and the improvement process of an urban environment, as "placemaking" (Pendlebury \& Porfyriou, 2017).

The growth of both cities and tourism has a significant impact on heritage and the appreciation of its value so that the relationship between the surrounding heritage and residents plays an important role in the urban regeneration process (Drury \& McPherson, 2008; Loulanski, 2006; Tweed \& Sutherland, 2007). Such dimensions of heritage as intensions and behaviour; heritage reputation, and beliefs/attitudes towards heritage develop an understanding of future challenges in urban regeneration (Monteiro et al., 2015).
As cultural heritage is a shared resource and part of the cultural identity of communities and individuals, an evolving area is the involvement of new audiences and the continuous development of participatory interpretation and governance models (Teller \& Bond, 2002). Community involvement can be classified according to the level of public impact: inform, consult, involve, collaborate, empower. The lower level of involvement is "inform," which ensures the provision of balanced and objective information on time, while the greater level of involvement, "empower," places final decision-making in the hands of the public (International Association for Public Participation, 2021).

Urban regeneration is the process that requires the interconnection of different strategies and objectives, and collaboration between various actors. Different scholars have stressed the importance of different actors' involvement, including local communities, city authorities, property owners, environmental organisations, investors, etc. Collaboration between actors on different stages of urban regeneration, like preliminary studies, the definition of objectives, planning, and implementation is a complex and long-term process (Roberts, 2000; Tanrikul \& Hoskara, 2019). The scale of urban regeneration influences the variety and types of involved actors and necessities for institutional action, management models, communication, participation, and financing. Digital placemaking offers an opportunity for new models of collaboration of these different actors within various scales of urban regeneration projects.

"Placemaking can be understood as an intentional process of situating, revealing, and creating meaningful environments" (Freeman, 2020, p. vii). The Project for Public Spaces, which is known to have played an important role in advancing the placemaking movement in the US, began consistently using the term "placemaking" in the mid-1990s. According to Project for Public Spaces:

Placemaking inspires people to collectively reimagine and reinvent public spaces as the heart of every community. Strengthening the connection between people and the places they share, placemaking refers to a collaborative process by which we can shape our public realm to maximise shared value. (Project for Public Spaces, 2018, p. i)

It is a multi-faceted approach to connect people to a place, urban planning, and to the design and management of public spaces. While the placemaking movement has flourished globally in the last two decades, the concept behind placemaking can be traced back to the 1960s: The ideas introduced by Jacobs' "eyes on the street," Whyte, who emphasised essential elements for creating social life in public spaces, and Gehl's (2010, p. 193) claim to cities in his famous quote-"First life, then spaces, then buildings. The other way around never works" (Foth, 2017; Gehl, 2010; Jacobs, 1961; Strydom et al., 2018; Whyte, 1980). "Placemaking" in a digital 
sense refers to digital applications which allow the transitional method of placemaking strategies to extend.

With the development of digital technologies and digital culture over the last ten years, opportunities afforded by information and communication tools and the emergent field of ubiquitous computing started to be identified, studied, and applied to the built environment. The growth of public Wi-Fi service and smartphone usage enabled devices to reshape how we plan and design cities and public places; it has also led to the rise of the term "digital placemaking." Digital placemaking is an emerging area of research and practice that focuses on the integration of social media and digital technologies within placemaking (Toland et al., 2020). It boosts the social, cultural, environmental, and economic value of places and fosters deeper relationships between people and the places they inhabit (Morrison, 2020). Digital placemaking can also be considered as a part of the wideranging and rapidly burgeoning literature on the blurring of physical, digital, social, and spatial experiences through the proliferation of smartphones, social media platforms, or loT and Al applications (Griffiths \& Barbour, 2016; O'Neill, 2016).

Spatially, digital placemaking opens up a "hybrid space" between the physical and the digital world. It contributes to the impression of a world in liquid where the "space of flows" dominates the "space of places." While on the more personal scale multiplying public and private uses of digital media, this phenomenon is consistent with Bauman's (2000, p. 11) liquid modernity; as he mentioned, "the advent of cellular telephones may well serve as a symbolic "last blow" delivered to the dependency on space." Digital placemaking is not meant to replace real places; it is about assisting placemaking to make a place stronger and more durable than what already exists. Despite all the opportunities offered by digital placemaking, there are also challenges like those of exclusion and the fear of privacy loss, which may directly influence the level of different community group involvement. With the rising use of digital technologies, people are becoming disconnected from places and left to self-definition of identity.

The global availability of information also promotes the phenomena of universal and unified solutions in urban regeneration processes. Consequently, highlighting local identity by focusing on cultural heritage and identifying its values is becoming increasingly important. Still, the meaning of cultural heritage is discussed in connection with its identification (Rautenberg, 1998; Teller \& Bond, 2002). Heritage is a broad notion which embraces diverse categories. The listed heritage objects and sites (e.g., World Heritage List, local heritage lists, etc.) undergo the traditional process of evaluation by experts. Most commonly, identification and inclusion in the heritage list is a top-down process, where less room is given to public involvement. On the other hand, the growing democratisation of culture shows how local communities define their own heritage values. Attitudes and behaviour towards certain objects and places define these places as valuable by determining their historical and cultural value for the general public. Thus, the growing inclusiveness and public participatory processes allow recognising heritage and its relation to the place's identity and sense of belonging. Moreover, the sense of belonging to the place raises public responsibility and interest in the place (Rautenberg, 1998).

Digital placemaking employs possibilities of virtual space to support the functioning of urban spatial structure. Virtual space, virtual reality, or virtual environment presents an environment in which various subjects are "continuously producing, packaging, re-packaging, recording, discarding, modifying, transferring, disseminating, accessing, and using information" (ScienceDirect, n.d.). Virtual spaces are divided into non-immersive (e.g., web page or smart app which submits simple information about a certain place), semi-immersive (e.g., games which partially replace stimuli of physical space), and fully immersive (e.g., program for virtual reality). All three types can have a different role and significance in digital placemaking, but the presented research focuses mostly on the non-immersive virtual spaces of each case: in Kaunas, it focuses on the most widely accessible non-immersive spaces, such as webpages; in Taiwan, it focuses on the information platform and the database system; and, in Riga, on the digital platform based on an open-source content management system (CMS). Information in virtual spaces can add to or modify the majority of aspects of the above-mentioned model of place according to the Project for Public Spaces concept (Project for Public Spaces, 2007). The hybrid space is understood as a place where the most important spatial structures in terms of placemaking and virtual spaces in terms of the amount of information overlap.

When a person is in a public space, their attention can therefore be focused on the point at which physical and digital space interconnect. This new hybrid space expands the range of ways a person can experience the physical space around them. (Morrison, 2020)

Morrison's Digital Placemaking Guide (2020) highlights semi-immersive or immersive virtual reality as one of the formants of hybrid spaces, but the fact that "attention and memory cannot operate without each other" (Chun \& Turk-Browne, 2007, p. 177) allows to see a non-immersive virtual environment as a formant of hybrid spaces too.

\section{Methodology and Approach}

Digital placemaking encompasses a variety of approaches, methods, and tools which can be used for different purposes. In general, digital placemaking aims to improve relationships between people and places (Marques \& Borba, 2017; Morrison, 2018; Wyckoff, 2013). For that reason, digital technologies can be implemented 
on different stages of urban regeneration as supporting collaborative processes through multi-stakeholder engagement at the early stages of project development while collecting feedback on development visions and as a tool for co-creation of places (Fredericks et al., 2018).

This research uses a practice-based approach to explore the diverse ways in which digital placemaking can be used for urban regeneration and the identification of heritage values. As digital placemaking is an emerging practice, this approach enables actors to map out commonalities and differences across different case studies and define the opportunities and challenges of each case. The chosen cases include the urban regeneration of the Dadaocheng (Taipei) historical district, the regeneration of interwar modernism architecture sites in Kaunas, and the regeneration within the Riga historical centre and beyond.

The Dadaocheng historical district, as one of the most successful examples for Taiwan's urban regeneration, demonstrates a balance between cultural preservation and industrial revitalisation. However, most of the online tools for obtaining information regarding urban development are based on government-related platforms, as well as sensor data, such as population, land use, urban planning, land ownership, regional historical maps, and geographic information systems, which can be obtained from the national research centre in Taiwan. In addition to dedicated official platforms, other data regarding social, cultural, and economic related information are often scattered across various websites. In recent years, urban regeneration issues have been highly valued and related data are in demand but rarely provided. It triggers the opportunity to develop a Dadaocheng information platform as a collective information hub for share knowledge, updated news, and stories from the past. As various types of information can cooperate into an organised system, it helps to better understand local situations from different aspects and it promotes cultural heritage tourism.

In Kaunas, the investigation of interwar modernism architecture potential for placemaking and digital placemaking based on the hybrid space concept was conducted while combining few methodologies. The identification of the most active/important physical spaces for placemaking was made using the space syntax approach, which is a type of mathematical graph model (Hillier, 1996). Its essence: urban spaces make a graph which is represented by nodes (streets or street segments) and edges (crossroads). The calculation of the centralities of the nodes serves as a background for calculation of space syntax indicators, such as choice (transit flows) and integration (the most reachable and accessible zones). In appearance, space syntax was criticised because of the generalisation and subjectivity of axial maps which were used to create mathematical graphs (Ratti, 2004). The introduction of a segment map (Hillier \& lida, 2005; Turner, 2004) modified the model and created premises necessary for its objectivisation while using GIS street maps for analysis (Kolovou et al., 2017). Space syntax models are validated in many pieces of research which describe configurations of a network of urban spaces with a focus on its potential social content, e.g., transit movement, attraction points, areas of social interaction, etc. Such concepts of placemaking as proximity, connectivity, accessibility, walkability, etc., could be easily measured using corresponding space syntax indicators. In some cases, space syntax models are used in connection with placemaking (Gurkas, 2010; Patil \& Raj, 2013). In terms of digital placemaking, space syntax could be used for modelling hybrid space physical components. The space syntax graph model was additionally validated in Kaunas while using different data. Statistical analysis of the data demonstrated moderate and strong person's correlations (up to 0.587 ) versus allocation of the most functionally important objects and commercial establishments and strong significant Spearman's correlation (up to 0.654) versus the density of the same objects. Because of the fundamental importance of movement in the city, the previously mentioned part of the place model (Project for Public Spaces, 2007) focused on the accessibility of urban physical spaces was chosen. All six aspects of accessibility were identified and measured using space syntax calculations. Six placemaking access aspects were modelled based on the following syntactic indexes: readability as intelligibility (Hillier, 2015), continuity as embeddedness (Yang \& Hillier, 2007), walkability based on a World Bank report (Fang, 2015) as metric reach (Peponis et al., 2008) weighted by building perimeter, proximity as integration within close pedestrian reach (500 metres), transport-oriented development convenience as multiplication of pedestrian integration and public transport, and accessibility as distance (metric step depth) from the main parking lots. Space matrix (Berghauser Pont \& Olsson, 2017; Ye \& van Nes, 2014), as a tool that allows combining and generalising different information and classifying it based on statistical cluster analysis, was used for the combination of six syntactic layers and identification of the areas with the biggest potential for placemaking. Information about the most often mentioned objects of the investigated area in Google search in Lithuanian was performed from Kaunas, thus reflecting the local situation. The results were mapped in GIS and space matrix of hybrid spaces, based on the previously-mentioned six quantitative qualities of physical space and information from the web. The matrix of hybrid spaces was compared with the allocation of modernistic cultural heritage buildings in the investigated area.

Participatory technologies have been deployed in a variety of built environment settings as a means of engaging with citizens on local issues using specific platforms (Krivy \& Kaminer, 2013). Nowadays, civil society and social urban movements in the Baltic states are emerging. A diversity of urban activism initiatives such as grassroots communities or neighbourhood associations, interest groups, politically- or culturally-oriented pressure 
groups, housing associations, groups against globalisation, and organisations for sustainable development and social justice are emerging all around the world. There has been significant growth of public participation initiatives in the process of urban regeneration in Riga since 2016. Urban regeneration is interconnected with the identification of neighbourhood identity. Local activists often exploit cultural heritage as a foundation for building local identity and foster the regeneration process. Thus, the case of Riga shows the use of digital media for community engagement in urban regeneration. To facilitate the participatory budgeting process in Riga, a competition has been organised on an online platform to support citizens' initiatives since 2019 (Riga City Council, 2021). On the online platform, NGOs, such as neighbourhood associations, publish prepared application materials, visualisations, descriptions, as well as approximate calculations. Then, every interested resident of Riga is invited to vote on the project application which is considered the most important, and thus the most significant and topical issues are expressed. During the two years, about 60 project proposals were submitted for the participatory budgeting competition. This study describes the intensity of public involvement in different neighbourhoods of Riga in the context of the topic of cultural heritage both in the historical core of the city and beyond.

\section{Case Studies: Digital Placemaking in Taiwan and the Baltic States}

\subsection{Dadaocheng Historical District in Taipei: Information Platform and Database System}

The Dadaocheng historical district in Taipei began to develop during the late Qing dynasty in the 1850 s.
In 1895, under Japanese colonisation, Dadaocheng became the centre of business, culture, and daily life for people in Taipei. During the 1980s, Dadaocheng became an urban fringe as a result of the expansion of Taipei. In 1997, a road widening policy for regenerating the declining Dadaocheng historic district in Taipei City roused a petition for the preservation of the old street. Through the planning of specific districts and regulations of bulk transfer for the historic site, the Dadaocheng historical district has been preserved, trying to aim the development towards the cultural tourism industry. The district has become a win-win case for Taiwan's urban regeneration, demonstrating that cultural preservation can balance with industrial revitalisation.

The Dadaocheng information platform was created to promote local culture and tourism industry, as well as to provide customised apps for increasing vitality for the urban regeneration. Two key aspects were designed, including the information platform and database system (see Figure 1).

The information platform gathers resources from Dadaocheng to develop a searchable database for users with easy access. Various categories are organised for assisting convenient information finding, such as Dadaocheng architectural and cultural assets, Dadaocheng celebrity and family, Dadaocheng industry and business, Dadaocheng historical map, Dadaochengrelated information platform, and Dadaochengrelated publications and research (see Figure 2). The Dadaocheng information platform encourages a mental connection between users and the site, provides knowledge from history to current events, from the story of celebrities to local architecture. Thus, related information enhances the impression of users regarding spatial quality and the urban condition. The development of the

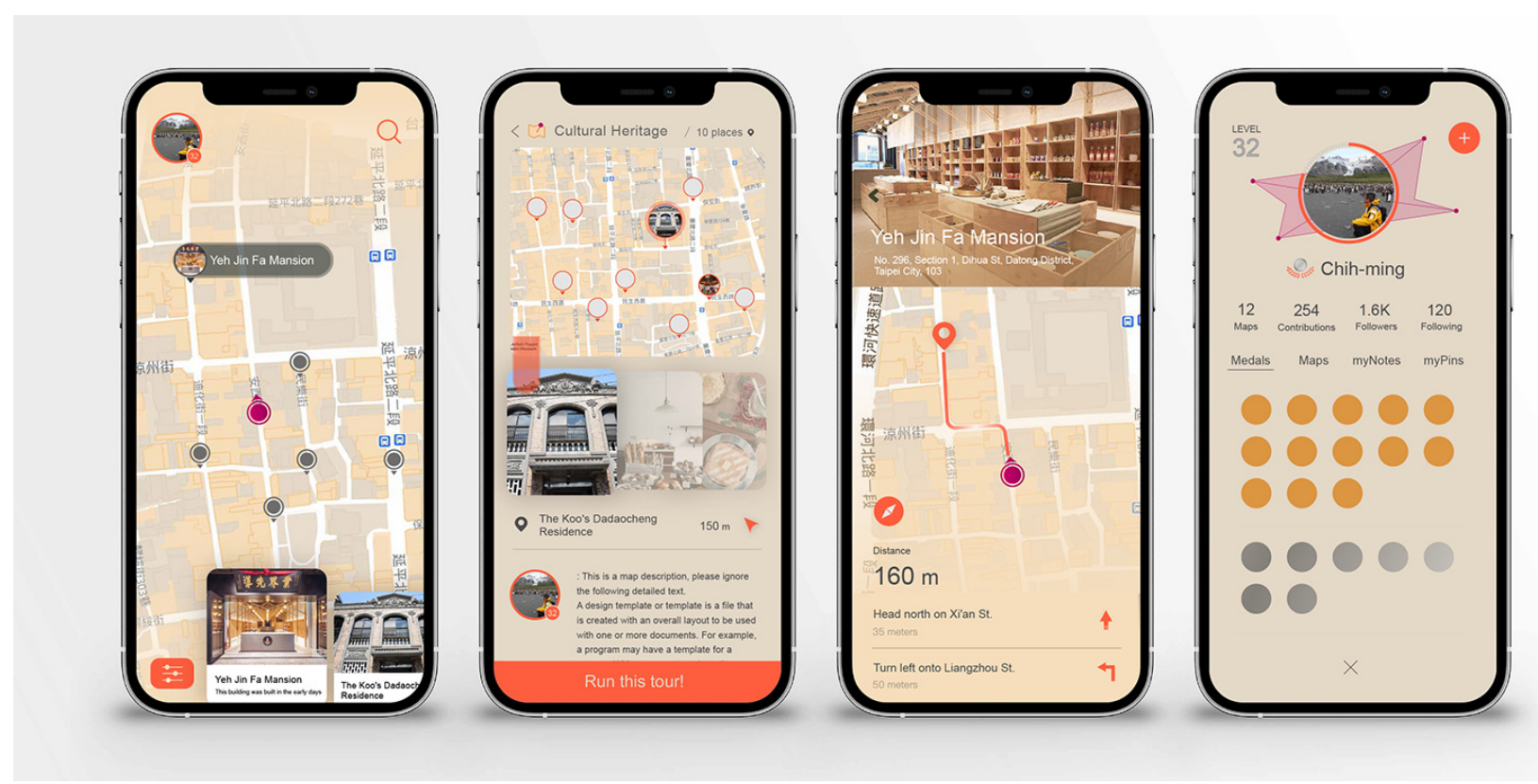

Figure 1. User interface. 


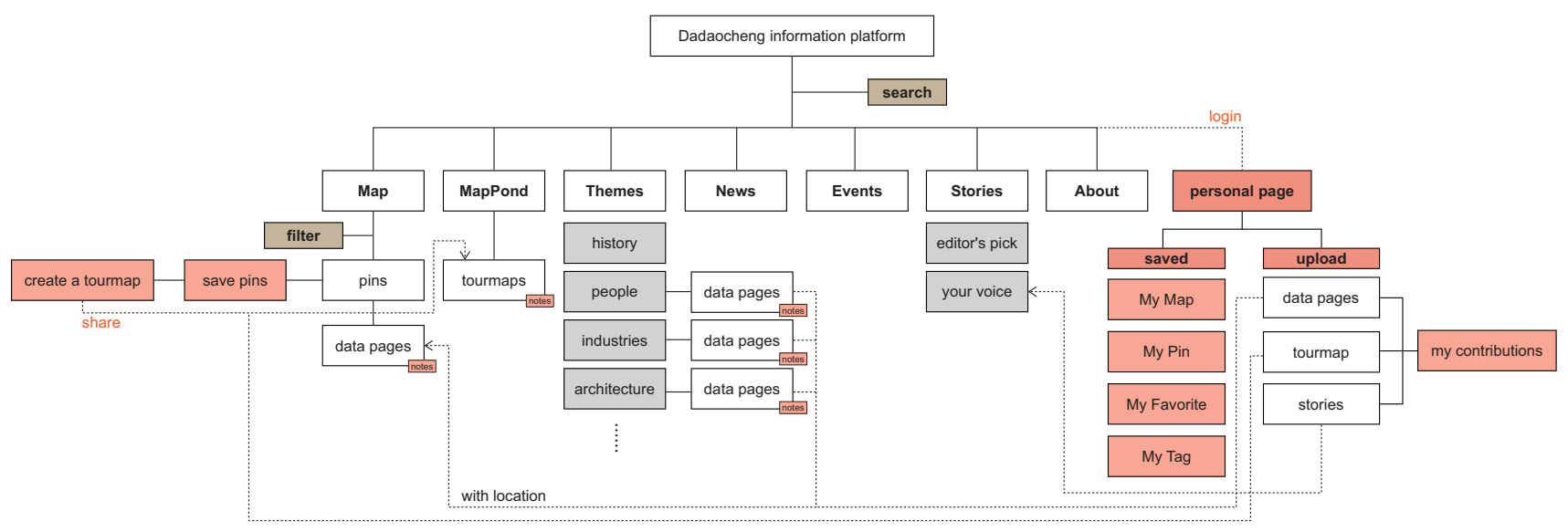

Figure 2. Overall structure.

database system is based on Notion and Google Maps. Adopting open-source software allows further development of a website and a smartphone application. Control of administration enables filtering information for web posting and data sharing to maintain the overall quality of the Dadaocheng information platform (see Figure 3 ).

To suggest further development of urban regeneration, specific functions were designed for the administration to better understand users' behaviour. Accordingly, to transform gained information into collectable data for conducting further research, functions such as the My Map document how different users prefer to travel and explain users' moving patterns. My Pin refers to personal preference of site attractions. Information of the Dadaocheng district regarding themes, news, events, stories, can be saved in My Favorite, which helps to imagine users' perception towards the site, based on the historical story of people, industries, architecture, or up-todate events and news according to different times of the year. My Tag allows the grouping of users with a similar preference for their shared post or viewing information, thus developing coherence interests towards other posts or users.

\subsection{Historical Kaunas City Centre: Space Matrix and Simulative Bottom-Up Modelling}

Historical Kaunas city centre was and is actively formed during various periods: Old town development could be traced back to the 12th century AD with introduction of the Gothic Plan around 1540 and the inclusion of buildings of various architectural styles until now; New Town was planned in 1845 in Classicism-like fashion under the occupation of the Russian empire as an expansion of the Old Town; it got the first push for more rapid development with the construction of Kaunas fortress in 1882-1915 and especially during the period of the first independence in 1918-1940, when Kaunas became the temporary capital of Lithuania. During the period of the second Soviet occupation (1944-1990) and since the 1990s, this area has functioned as a vibrant city centre. It is confirmed by the actual Kaunas City Master
Control

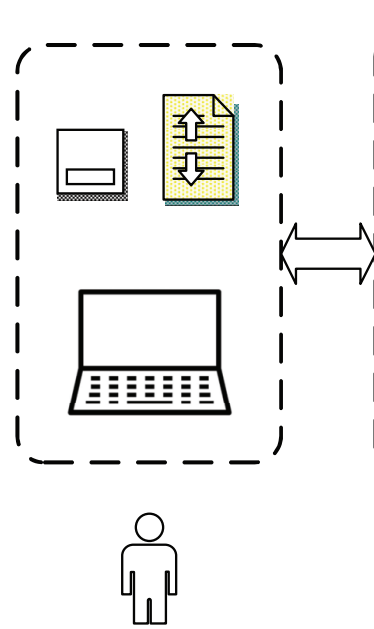

Administrator
Platform

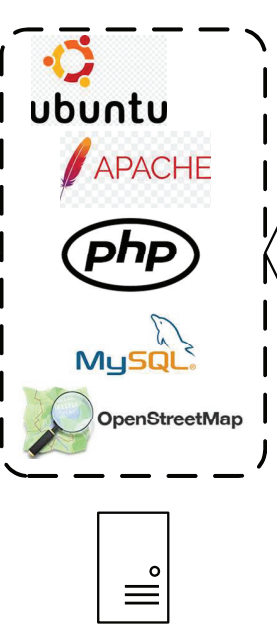

Server
Interface

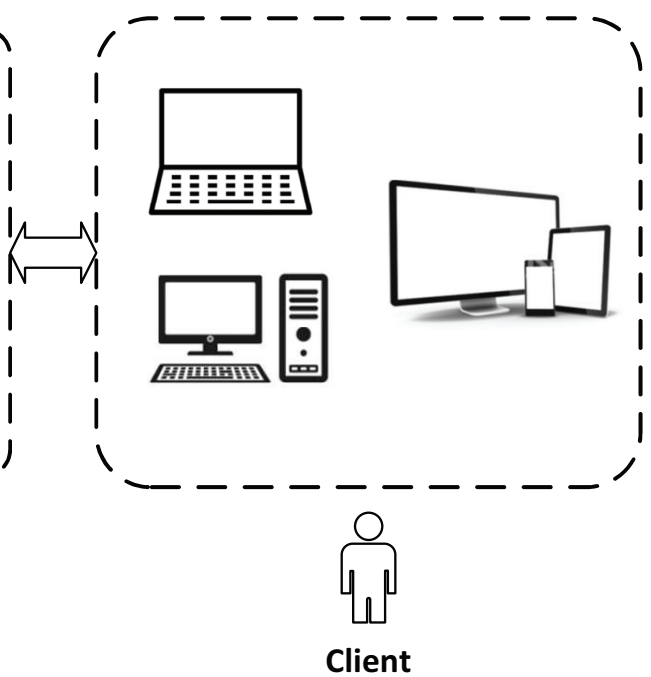

Figure 3. Operation system. 
Plan, that both the Old and New Town zones of cultural heritage protection and city centre, which consists of mixed land use and intensity of buildings (ratio between building area and land plot is equal to 3.5; Kaunas City Municipality Administration, 2014b). The City Master Plan points out interwar modernism architecture and the entire investigated territory as the most significant formant of the city's identity (Kaunas City Municipality Administration, 2014a). Nomination for inscription on the UNESCO World Heritage List of Kaunas interwar modernism (Kaunas Region, 2021) in the proposed management plan of the heritage highlights the importance of collaboration with local society for heritage preservation. In such a situation, the issue to preserve urban identity and combine it with new development becomes a challenging task that could not be successfully addressed without the involvement of society and contemporary tools of placemaking. It is especially true if the so-called interwar modernism architecture is considered. On the one hand, it is highly valued by the professionals as a part of the Kaunas European Capital of Culture 2022 event and submitted as a candidate for the UNESCO World Heritage List as a unique heritage type in Eastern Europe and Lithuania; on the other hand, it could not be effectively protected and utilised without the involvement of the wider society through education, an increase of visibility, etc. The interwar modernism architecture, based on both efforts of professional historians and its cultural association to the First Republic of Lithuania (1918-1940), becomes a powerful cultural symbol that could be utilised in many spheres of functioning of urban reality (marketing, tourism, local cultural narratives building, etc.) and whose significance is not discussed in Lithuania. The travelling national and international exhibition "The Architecture of Optimism" could serve as an illustration for the increased visibility of modernistic architecture (Kaunas 2022, n.d.).

The Kaunas case evaluates how significant the role of modernism architecture is for placemaking and digital placemaking in the city centre, addressing it through the eyes of the local inhabitants. Placemaking potential aspects are addressed based on space syntax analysis. Digital placemaking analysis investigates which objects and to what degree of intensity, including heritage, are present in the non-immersive virtual spaces as the only widely available spaces. The presence was measured based on photographic search results from IP addresses located in Kaunas while using such keywords as "Kaunas + Old Town/New Town + Buildings" (in Lithuanian). The first 1,000 search results were analysed. The combination of urban spaces considered most important for placemaking and non-immersive virtual spaces were used to identify the hybrid spaces in Kaunas. The GIS database was created as a platform for analysis. To combine various types of data effectively, the space matrix methodology was used. It was performed in the following steps: the entire investigated area was tessellated into square polygons of $100 \mathrm{~m}$ by $100 \mathrm{~m}$; the net- work of the polygons was intersected with separated layers of data as space syntax indicators, allocation of heritage, etc.; the classification of spaces based on the potential for placemaking and digital placemaking was made based on statistical cluster analysis of the information in the space matrix. Cluster analysis identified the Old Town and two big "islands" in the New Town allocated along the main pedestrian street as the areas with the biggest potential for placemaking. The buildings most often found in the Google search were identified based on the 2,000 first results $(1,000$ for each part). Subsequently, 162 objects repeated from 58 to 1 time in the Google search were mapped. The mean repetition rate is 4.44 , demonstrating how often each picture of a physical building was found during the Google search, which can serve as a benchmark for the number of times each precise building is mentioned. The matrix of virtual space, if compared to the physical one, is much more scattered, but still its highest values are concentrated inside or around the most important clusters of the accessibility matrix. Modernistic buildings are mainly represented at the periphery of the New Town and all repeated just once. The main research steps and results, as well as space syntax indicators used for space matrix, are summarised in Figure 4.

\subsection{Riga: Digital Platform Based on Open-Source Content Management System}

The historical centre of Riga is included in the UNESCO World Heritage List. The site reflects various architectural styles, which provide valuable insight into the stages of development of Riga as a city (UNESCO, 2021). Thus, protection and urban regeneration for this part of the city get more attention. Unfortunately, regeneration actions and identification of the value on the fringe of the city is not very active. Greater community involvement and participatory actions create an opportunity to identify tangible and intangible heritage values and to support the regeneration of places both in the centre and on the fringe of the city in a more unified and fair way.

Participatory planning and co-creation can increase the efficiency of regeneration proposals and help to create spaces, which will be used by local inhabitants (Kamrowska-Zaluska, 2016; Krivy \& Kaminer, 2013). As sustainable development is the main goal of many cities, ensuring public participation in urban regeneration is crucial while searching for effective long-term solutions (Laws et al., 2004). Digital technologies can be implemented on different stages of urban regeneration: e.g., supporting collaborative processes through multistakeholder engagement at the early stage of project development while collecting feedback on development visions, and as a tool for co-creation of places (Fredericks et al., 2018).

In 2019, the Riga City Council launched a new participatory budgeting pilot program called For Riga Neighbourhood Development Project Realisation (Riga 


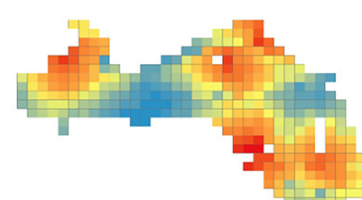

Acessibility (Metric step depth)

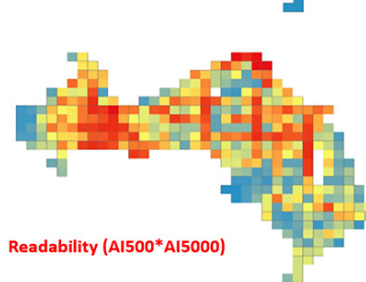

Readability (A1500*A15000)

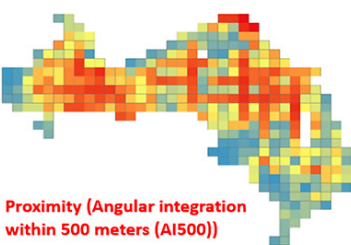
within 500 meters (A1500))
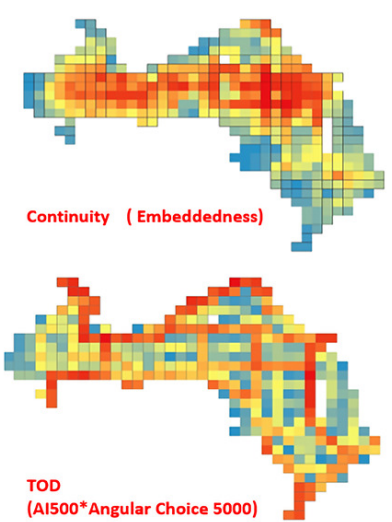

(Al500*Angular Choice 5000)

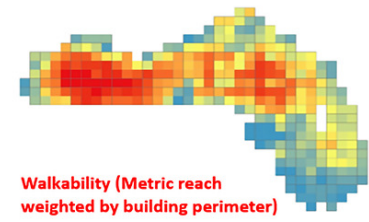

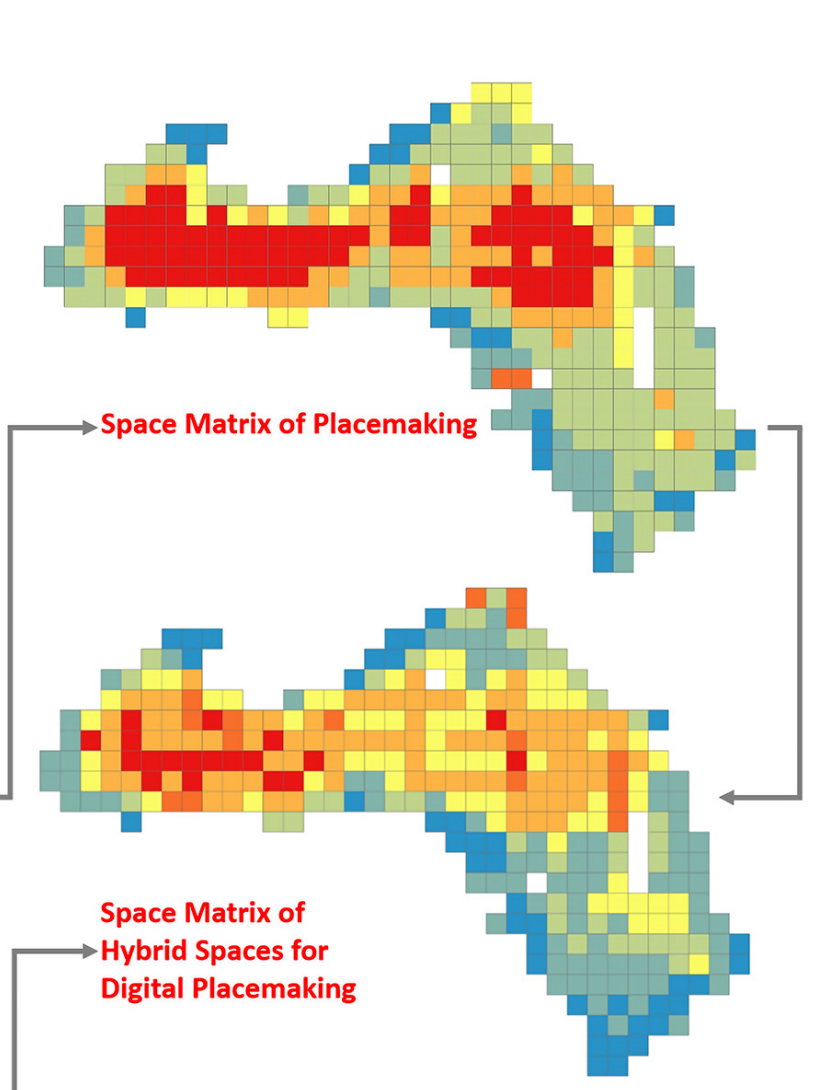

Repetition of buildin in WWW space
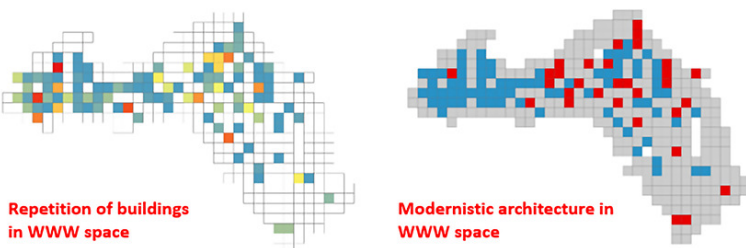

Space Matrix of

Hybrid Spaces for WWW space$$
\text { - }
$$

Figure 4. Construction of space matrixes for placemaking and digital placemaking. The red colour indicates the high importance of areas for placemaking in all maps except "World Wide Web [WWW] spaces." The red colour identifies positions of modernistic architecture there.

City Council, 2020, 2021). The digital platform of the program is based on the open-source CMS (Drupal, 2021), providing an integrated back-end and front-end solution for easy content authoring, reliable performance, and security both for desktop, as well as for mobile users. The CMS is integrated with Google Maps web mapping service for visualisation of GIS data. The electronic voting for submitted projects is organised through integration with the state service portal (latvija.Iv). The digital platform is also integrated with the social networking platforms Facebook and Twitter. The GIS data on the project webpage shows how many projects have been submitted in each neighbourhood and allows analysing how fragmented the urban regeneration process is. Also, it facilitates the search for projects in specific neighbourhoods while voting.

In total, 58 project proposals have been submitted during the first two years of the program: 34 proposals in 2019 and 24 proposals in 2020 . More detailed information is presented online (Riga City Council, 2020, 2021). The most active neighbourhoods in terms of number of submitted projects in 2019-2020 are Centrs, Agenskalns, Teika, Imanta, Vecmilgravis, Sarkandaugava, Mangalsala, and Jaunciems (see Figure 5). Four out of 12 approved projects are in neighbourhoods that are inside or partly inside the Riga historical centre and its protection zone.
Results show that the local community supports the regeneration and creation of identity and local landmarks (e.g., Agenskalns, Centrs), as well as projects that support the development/regeneration of passive and active recreation sites (e.g., Brasa, Teika). Thus, the tool appears to be an effective approach to support regeneration outside the historical centre (Figure 6).

\section{Findings and Discussion}

As seen from the presented cases, each of the described solutions has common foundational features oriented to identify the role of heritage values within the urban regeneration process. However, the used digital technologies and implementation details are different for each of the cases reflecting the fact that currently there are no unified standards for the development of information technology platforms in the area of digital placemaking. The case of Kaunas presents the most advanced and full-fledged GIS usage for analysis of urban activities, in comparison to the cases of Riga and Dadaocheng. In the case of Riga, the digital participation and involvement of users in the evaluation and voting for various city projects play a vital role. However, the usage of GIS is limited mainly to the mapping and information presentation levels. The Dadaocheng information platform is similar in 


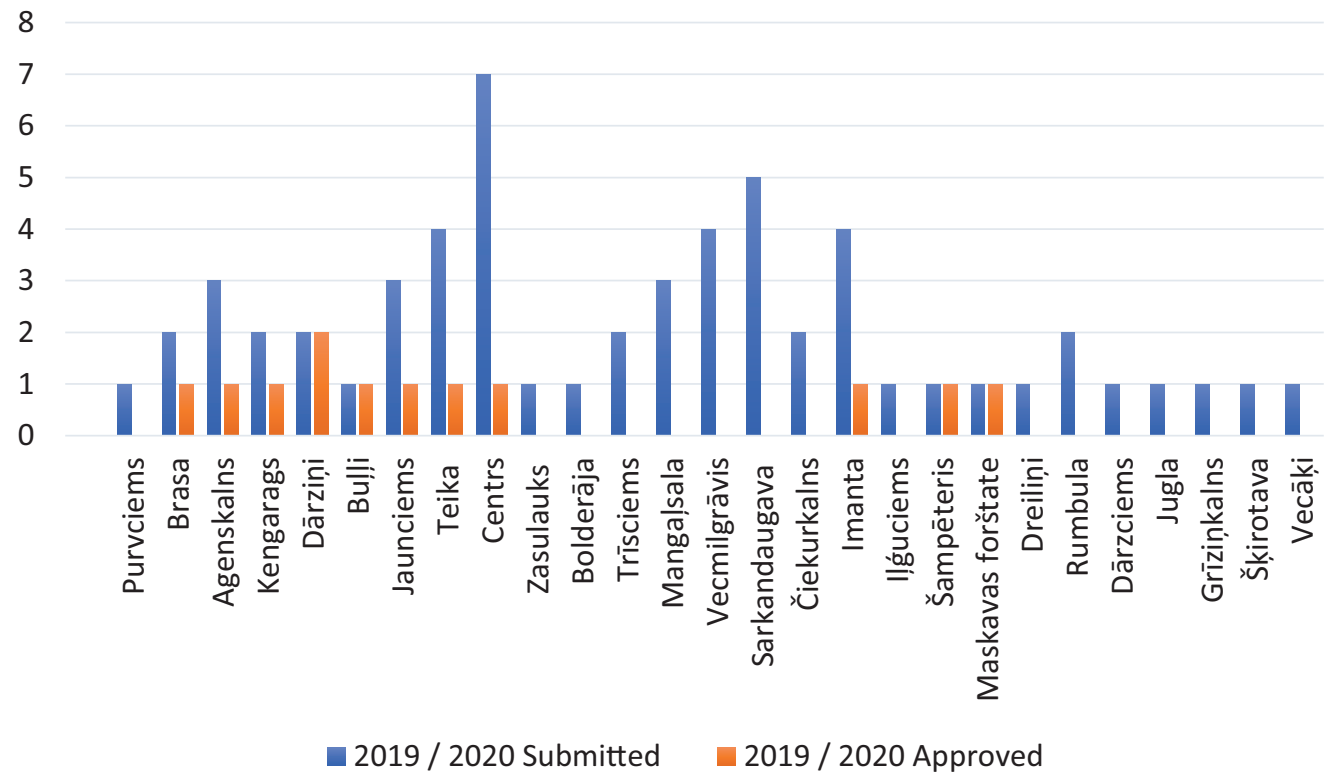

Figure 5. Submitted and approved projects in relation to neighbourhoods.

that sense to Riga's case because the usage of geographic data is limited to web-mapping purposes. From a highlevel technological point of view, the digital platform for Dadaocheng is conceptually similar to the platform used in Riga adopting open-source software for participatory urban solutions.

Table 1 presents the key characteristics and configurations of the digital placemaking tools in Dadaocheng, Kaunas, and Riga. In all three cases, local people appear to play a crucial role in the effective operation of the tool, being involved actively (direct interaction with the digital platform) or passively (providing data for analysis). In the case of Dadaocheng, the digital tool encourages a better understanding of heritage site value and allows changes in perception. In Kaunas, the tool allows making heritage more visible based on the targeted actions in both virtual and hybrid spaces. In Riga, the tool allows proceeding with regeneration actions not only in the listed heritage sites but also in areas chosen by local people and considered valuable for the local community. Here, GIS allows easy searching for regeneration projects in specific neighbourhoods.

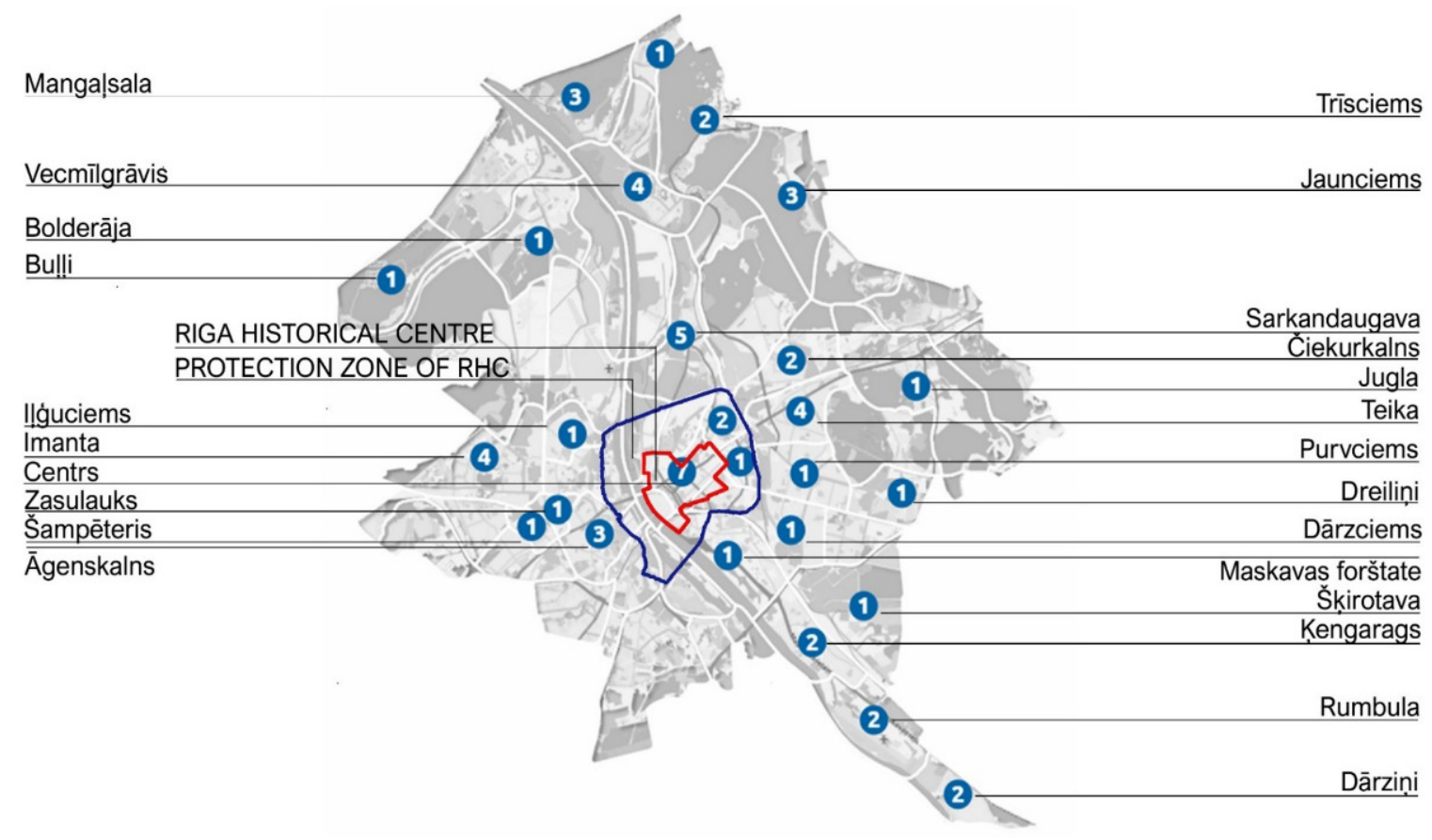

Figure 6. Geographical distribution of submitted projects. Source: Authors' work, based on Riga City Council (2021). 
Table 1. Key characteristics and configurations of the digital placemaking tools.

\begin{tabular}{|c|c|c|c|c|}
\hline TOOL & & $\begin{array}{l}\text { Information platform } \\
\text { and database system. }\end{array}$ & $\begin{array}{l}\text { Space matrix and } \\
\text { simulative bottom-up } \\
\text { modelling. }\end{array}$ & $\begin{array}{l}\text { Digital platform based } \\
\text { on open-source CMS. }\end{array}$ \\
\hline SCALE & & District; regional scale. & $\begin{array}{l}\text { District or few districts } \\
\text { (city centre). }\end{array}$ & $\begin{array}{l}\text { City scale; } \\
\text { neighbourhood scale. }\end{array}$ \\
\hline ACTORS & & $\begin{array}{l}\text { Users: Residents, store } \\
\text { owners, local tourists, } \\
\text { foreign tourists. }\end{array}$ & $\begin{array}{l}\text { Academia and } \\
\text { residents. }\end{array}$ & $\begin{array}{l}\text { Residents, NGOs, and } \\
\text { the municipality. }\end{array}$ \\
\hline \multirow[t]{2}{*}{$\begin{array}{l}\text { COMMUNITY } \\
\text { INVOLVEMENT }\end{array}$} & $\begin{array}{c}\text { Active } \\
\text { Consult, involve, } \\
\text { collaborate, empower }\end{array}$ & $\begin{array}{l}\text { Interaction with the } \\
\text { digital platform. }\end{array}$ & & $\begin{array}{l}\text { Voting, co-planning, } \\
\text { and co-design. }\end{array}$ \\
\hline & $\begin{array}{c}\text { Passive } \\
\text { Inform, observe, } \\
\text { analyse }\end{array}$ & $\begin{array}{l}\text { Collectable data } \\
\text { analysis (My Map, My } \\
\text { Pin, My Favorite, My } \\
\text { Tag). }\end{array}$ & $\begin{array}{l}\text { Analysis of simulated } \\
\text { urban structure and } \\
\text { web content analysis. }\end{array}$ & $\begin{array}{l}\text { Analysis of inhabitants' } \\
\text { level of involvement, } \\
\text { types of supported } \\
\text { projects, etc. }\end{array}$ \\
\hline \multirow[t]{3}{*}{$\begin{array}{l}\text { VIRTUAL } \\
\text { SPACE }\end{array}$} & $\begin{array}{l}\text { Non-Immersive } \\
\text { E.g., web page or } \\
\text { smart app which } \\
\text { submits simple } \\
\text { information about a } \\
\text { certain place }\end{array}$ & $\begin{array}{l}\text { Web pages for } \\
\text { supporting } \\
\text { comprehensive } \\
\text { information for this } \\
\text { district. }\end{array}$ & $\begin{array}{l}\text { Web pages both } \\
\text { specialised and } \\
\text { general. }\end{array}$ & $\begin{array}{l}\text { Digital platform, which } \\
\text { supports involvement, } \\
\text { collaboration, and } \\
\text { empowerment of local } \\
\text { people. }\end{array}$ \\
\hline & $\begin{array}{l}\text { Semi-Immersive } \\
\text { E.g., game that } \\
\text { replaces partially } \\
\text { stimuli of physical } \\
\text { space }\end{array}$ & $\begin{array}{l}\text { Allowing different } \\
\text { users to share } \\
\text { thoughts and news. }\end{array}$ & $\begin{array}{l}\text { Could be created } \\
\text { based on the } \\
\text { conducted research on } \\
\text { non-immersive virtual } \\
\text { spaces. }\end{array}$ & $\begin{array}{l}\text { Could be created } \\
\text { based on submitted } \\
\text { projects and } \\
\text { qualitative } \\
\text { visualisations. }\end{array}$ \\
\hline & $\begin{array}{l}\text { Fully Immersive } \\
\text { E.g., program for } \\
\text { virtual reality }\end{array}$ & $\begin{array}{l}\text { Travelling routes are } \\
\text { shared as a visiting } \\
\text { guide for various } \\
\text { purposes. }\end{array}$ & & $\begin{array}{l}\text { Could be created } \\
\text { based on submitted } \\
\text { projects, for a better } \\
\text { understanding of } \\
\text { urban regeneration } \\
\text { visions. }\end{array}$ \\
\hline \multirow[t]{3}{*}{$\begin{array}{l}\text { HERITAGE } \\
\text { VALUE }\end{array}$} & $\begin{array}{c}\text { Intentions and } \\
\text { Behaviour Towards } \\
\text { Heritage }\end{array}$ & $\begin{array}{l}\text { Encouraging better } \\
\text { understanding of site } \\
\text { value by sharing local } \\
\text { information. }\end{array}$ & $\begin{array}{l}\text { Check if it is a part of } \\
\text { virtual space and } \\
\text { hybrid space and } \\
\text { create a background } \\
\text { for its activation in } \\
\text { both spaces. }\end{array}$ & $\begin{array}{l}\text { Allows submission of } \\
\text { projects focused on } \\
\text { heritage protection } \\
\text { and regeneration. } \\
\text { Improves and raises } \\
\text { the value oflocal } \\
\text { community-supported } \\
\text { sites. }\end{array}$ \\
\hline & Heritage Reputation & $\begin{array}{l}\text { This district has been } \\
\text { valued highly by locals } \\
\text { and governments. }\end{array}$ & $\begin{array}{l}\text { Heritage is seen as an } \\
\text { iconic symbol and a } \\
\text { state's cultural } \\
\text { progress. }\end{array}$ & $\begin{array}{l}\text { Raises awareness } \\
\text { regarding regeneration } \\
\text { and allows } \\
\text { understanding of } \\
\text { community } \\
\text { preferences. }\end{array}$ \\
\hline & $\begin{array}{l}\text { Beliefs and Attitudes } \\
\text { Towards Heritage }\end{array}$ & $\begin{array}{l}\text { This district serves as a } \\
\text { regional cultural hub } \\
\text { since an early period. }\end{array}$ & $\begin{array}{l}\text { Heritage could be } \\
\text { made more visible } \\
\text { based on targeted } \\
\text { actions in both virtual } \\
\text { and hybrid spaces. }\end{array}$ & $\begin{array}{l}\text { Raises awareness of } \\
\text { heritage objects and } \\
\text { sites. }\end{array}$ \\
\hline
\end{tabular}


The Dadaocheng information platform is designed to encourage users to explore this operation system and aims to develop the local information hub. It focuses on the connection between the mentality of users and the physical condition of the urban environment. The development of urban environment is always according to the perspective of local government, which can also be referred to as a top-down approach. However, the collection of data regarding the mental impression and behaviour of users concerning the urban condition allows better suggestions from a bottom-up approach. It not only demonstrates the real situation but also sets the direction of future improvement for urban designers and planners to better bridge the gap between the perspective of governments and local communities, as well as taking up the challenge of urban regeneration.

In Kaunas, the space matrix of digital placemaking based on current situation analysis of Google search results demonstrates quite weak relations between modernistic architecture and areas with the highest potential for placemaking (Table 2). A not very strong but significant correlation could be observed between existing objects during the Google search and quite a large number of space syntax indexes, thus confirming the premise that non-immersive virtual spaces are at least partially related to more intensive movement and activities of people in a physical urban space. Weak and moderate correlations between human activity patterns as identified by space matrix and the physical allocation of cultural heritage objects might mean that the latter could be more actively involved in placemaking while employing semi-immersive or immersive virtual tools.

Research results in Kaunas (Figure 4) demonstrate quite a fragmented and scattered picture of hybrid spaces despite some specialised activities such as memory maps (Atminties vietos, 2020) or various Kaunas 2022 digital initiatives (Kaunas 2022, n.d.). The same is true if modernistic architecture is considered: There is very little overlapping with the map of hybrid spaces and, even if 41 out of 162 Google searches pointed out modernistic buildings, they were all mentioned just once while the mentioning of the other objects varies from 53 to one with mean 4.44. Statistical analysis reveals that Cramer's Association coefficient between the most important hybrid spaces and modernistic buildings is just 0.044, while with the other types of heritage is 0.373 . Such a situation could be explained by the peripheral location of the majority of modernistic buildings in the New Town and its lower attractiveness to a general audience if compared to more easily recognisable architecture from earlier historical periods. The open web-based database on heritage in Kaunas in the Archive of Architecture and Urbanism Research Center (Architektūros Ir Urbanistikos Tyrimų Centras, 2020) is not very effective in terms of relations to very general web search algorithms. Configurations of the digital matrix relatively concentrated around the main zones of the spatial accessibility matrix show that the web content approximately follows human flows in the city and more autonomous or interactive virtual spaces are needed to transform the matrix of hybrid spaces more effectively.

The analysed participatory budgeting tool in Riga is a step towards more active engagement of the community in the process of placemaking, by upgrading the traditional "informing" and "involving" to the visions and projects developed by local communities on the specific site they have chosen. Here, GIS is used by the municipality to illustrate the on-going processes. Still, this type of digital participation has some limitations and needs to be upgraded. For example, it reaches only certain demographics within certain communities. Therefore, participatory technologies should be deployed also in the urban environment by allowing the wider public to express their opinion "on the go."

In general, the conducted research proves potentially significant relations between digital placemaking through targeted and non-targeted creation of hybrid spaces for expansion of inhabitants' experiences and connections with historical places and immovable cultural heritage. Depending on local settings, the degree of involvement of local societies and available digital tools, the processes of digital placemaking can have different forms which might evolve from bottom-up generated to more precisely target-oriented activities.

Table 2. Pearson correlations in space matrix.

\begin{tabular}{lccc}
\hline & Modernism Presence & WWW Mentions & Heritage Presence \\
\hline Embeddedness or zones of a dispersed street network & $-0.132^{*}$ & $-0.135^{*}$ & $-0.302^{* *}$ \\
Choice or transit within $500 \mathrm{~m}$ & $0.126^{*}$ & $0.131^{*}$ & $0.281^{* *}$ \\
Integration or closeness within 1,000 m & $0.160^{* *}$ & 0.077 & $0.272^{* *}$ \\
Integration or closeness within $500 \mathrm{~m}$ & $0.108^{*}$ & $0.164^{* *}$ & $0.303^{* *}$ \\
Reachable length of a street network within $500 \mathrm{~m}$ & 0.078 & $0.162^{* *}$ & $0.352^{* *}$ \\
Reachable building perimeter within $400 \mathrm{~m}$ & 0.022 & $0.204^{* *}$ & $0.362^{* *}$ \\
Straightness of street network within $400 \mathrm{~m}$ & 0.000 & $0.193^{* *}$ & $0.348^{* *}$ \\
\hline
\end{tabular}

Notes: ${ }^{*}$ Correlation is significant at the 0.05 level (two-tailed); ${ }^{* *}$ correlation is significant at the 0.01 level (two-tailed). 


\section{Conclusions}

In the process of urban regeneration, the placemaking approach is used to form the identity of a place and to identify heritage value. The involvement of the local community in the process of urban regeneration and identification of heritage values is crucial for the creation of a mental connection to the place, ensuring a sense of belonging and so influencing people's behaviour and attitude towards heritage.

The information platform and database system in Dadaocheng district does not directly refer to the physical making of places, but through learning from the behaviour of users and appreciating the value of heritage, it triggers constructive design and planning strategies for opportunities of placemaking within the urban environment. Digital tools, such as the Dadaocheng information platform, can therefore enhance the urban character regarding social, cultural, and economic conditions for regeneration.

The space matrix and investigation of the content of non-immersive virtual spaces in Kaunas allowed identification of clearly defined and consolidated zones of spatial structure with the greatest potential in terms of placemaking. The case shows that non-immersive virtual space content more or less follows objects and territories which are not in such favourable spatial positions for placemaking. It means that only specific target-oriented, more immersive digital placemaking tools can compensate for limitations of physical spatial structure.

The digital platform based on an open-source CMS in Riga supports participatory budgeting processes. The advantage of this tool is the assistance provided in the creation of local identity and local heritage values. The tool allows the involvement of the local community in the identification of their own values, the places, and objects they consider as a priority in the urban regeneration process. Comparing to the regeneration of listed heritage sites, the tool also supports sites that might be of undefined value on a larger scale but are crucial for the local community and their quality of life. The tool supports the development of real urban regeneration projects.

In the process of digital placemaking, different cooperation models are possible: (1) residents, local tourists, foreign tourists, and private sector; (2) residents and academia; and (3) residents, NGOs, and the municipality. The type of the tool used defines the selected model and the level of engagement of different actors. The choice of a specific tool is determined by local opportunities and targets problem solving for various urban conditions.

GIS allows easy searching for regeneration projects in specific neighbourhoods and allows following up geographical distribution of urban regeneration. GIS-based technologies provide not only mapping tools for digital placemaking but could also serve as a powerful analysis and modelling platform of various digital tools' effectiveness.
As current trends show, digital innovations will play an increasingly important role in digital placemaking for urban regeneration in the future by transforming existing solutions into highly immersive intelligent predictive platforms tightly integrating advanced methods of augmented/virtual reality, simulation, and machine learning. The development of digital technologies will increasingly contribute to new opportunities and challenges in the maintenance and management of digital placemaking and will allow more comprehensive public involvement in this process. At the same time, it is vitally important to remember that successful digital placemaking solutions would be determined by people and place, but technology can only be an enabler of success and not the driver of a digital placemaking project of any scale.

\section{Acknowledgments}

This research is funded and conducted within the framework of the Taiwan-Latvia-Lithuania cooperation project Up-To-Date Information Systems in Urban Regeneration and is supported by the State Education Development Agency Republic of Latvia, the Ministry of Education, Science and Sport of the Republic of Lithuania, the Taipei Mission in the Republic of Latvia and Lithuania, and Taiwan's Ministry of Science and Technology (MOST 1092923-E-011-002-MY3).

\section{Conflict of Interests}

The authors declare no conflict of interests.

\section{References}

Architektūros Ir Urbanistikos Tyrimy Centras. (2020). Home. http://www.autc.It/en

Ashworth, G. J. (1997). Conservation as preservation or as heritage: Two paradigms and two answers. Built Environment, 23(2), 92-102. http://www.jstor.org/ stable/23288309

Atminties vietos. (2020). Map. Open Archives of Kaunas. https://www.atmintiesvietos.It/en/map

Bauman, Z. (2000). Liquid modernity. Polity Press.

Berghauser Pont, M., \& Olsson, J. (2017). Typology based on three density variables central to Spacematrix using cluster analysis. In D. U. Mondéjar, J. C. Alcácer, A. P. Mañanós, \& V. C. Sendra (Eds.), Proceedings 24th ISUF 2017-City and territory in the globalization age (pp. 1337-1348). Polytechnic University of Valencia. http://ocs.editorial.upv.es/index. php/ISUF/ISUF2017/paper/viewFile/5319/3569

Boussaa, D. (2017). Urban regeneration and the search for identity in historic cities. Sustainability, 10(1), Article 48. https://doi.org/10.3390/su10010048

Chun, M. M., \& Turk-Browne, N. B. (2007). Interactions between attention and memory. Current Opinion in Neurobiology, 17, 177-184. http://ntblab. princeton.edu/wp-content/uploads/2015/01/ 
Chun_CONB_2007.pdf

de Filippi, F., Coscia, C., \& Cocina, G. G. (2020). Digital participatory platforms for urban regeneration: A survey of Italian case studies. International Journal of E-Planning Research, 9(3), 47-67. https://doi.org/ 10.4018/IJEPR.2020070103

Drupal. (2021). Home. https://www.drupal.org

Drury, P., \& McPherson, A. (2008). Conservation principles, policies and guidance for the sustainable management of the historic environment. English Heritage.

Fang, K. (2015). Public transport and urban design. World Bank Blogs. https://blogs.worldbank.org/transport/ public-transport-and-urban-design

Foth, M. (2017). Some thoughts on digital placemaking. In H. M. Hausler, M. Tomitsch, L. Hespanhol, \& G. Tscherteu (Eds.), Media architecture compendium: Digital placemaking (pp. 203-205). Avedition GmbH.

Fredericks, J., Hespanhol, L., Parker, C., Zhou, D., \& Tomitsch, M. (2018). Blending pop-up urbanism and participatory technologies: Challenges and opportunities for inclusive city making. City, Culture and Society, 12, 44-53. https://doi.org/10.1016/j.ccs.2017. 06.005

Freeman, C. G. (2020). Foreword. In D. Hes \& C. Hernandez-Santin (Eds.), Placemaking fundamentals for the built environment ( $p$ p. vii-viii). Palgrave Macmillan.

Freeman, G., Bardzell, J., Bardzell, S., Liu, S.-Y., Lu, X., \& Cao, D. (2019). Smart and fermented cities: An approach to placemaking in urban informatics. In S. Brewster, G. Fitzpatrick, A. Cox, \& V. Kostakos (Eds.), CHI '19: Proceedings of the $2019 \mathrm{CHI}$ Conference on human factors in computing systems (Paper 44). Association for Computing Machinery. https://dl. acm.org/doi/pdf/10.1145/3290605.3300274

Gehl, J. (2010). Cities for people. Island Press.

Griffiths, M., \& Barbour, K. (2016). Making publics, making places. University of Adelaide Press.

Gurkas, E. T. (2010). Spatial segregation and place: Making practice in an urban space. In D. Koch, L. Marcus, \& J. Steen (Eds.), Proceedings of the 7th International Space Syntax Symposium (Paper 115). KTH Royal Institute of Technology. http://www.sss7.org/ Proceedings/08\%20Spatial\%20Configuration\% 20and\%20Social\%20Structures/S115_Tuncer.pdf

Hillier, B. (1996). Space is the machine. Cambridge University Press.

Hillier, B. (2015). Space is the machine: A configurational theory of architecture. CreateSpace Independent Publishing Platform. https://spaceisthemachine.com

Hillier, B., \& lida, S. (2005). Network and psychological effects in urban movement. In A. G. Cohn \& D. M. Mark (Eds.), Spatial information theory. COSIT 2005. Lecture notes in computer science (Vol. 3693, pp. 475-490). Springer. https://doi.org/10.1007/ 11556114_30

International Association for Public Participation. (2021).
IAP2 conferences \& events. https://www.iap2.org/ page/Conferences

Jacobs, J. (1961). The death and life of great American cities. Random House.

Kamrowska-Zaluska, D. (2016). Participatory budgeting in Poland: Missing link in urban regeneration process. Procedia Engineering, 161, 1996-2000. https:// doi.org/10.1016/j.proeng.2016.08.792

Kaunas 2022. (n.d.). Homepage. https://kaunas2022.eu/ en

Kaunas City Municipality Administration. (2014a). Kauno miesto identiteto formavimo schema [Kaunas city identity formation scheme]. http://www.kaunas.lt/ wp-content/uploads/sites/13/2019/05/3_Kauno_ miesto_identiteto_formavimas_25000.png

Kaunas City Municipality Administration. (2014b). Kauno miesto savivaldybès bendrasis planas [General plan of Kaunas city municipality]. http://www. kaunas.It/wp-content/uploads/sites/13/2015/06/ 02pagrindinisvienaslapas10000-1.jpg

Kaunas Region. (2021). Modernist Kaunas: Architecture of optimism, 1919-1939. Nomination for inscription on the UNESCO World Heritage List. https:// modernizmasateiciai.It/wp-content/uploads/2018/ 11/Modernist-Kaunas.-Nomination-Dossier2021.pdf

Kolovou, I., Gil, J., Karimi, K., Law, S., \& Versluis, L. (2017). Road centre line simplification principles for angular segment analysis. In T. Heitor, M. Serra, J. P. Silva, M. Bacharel, \& L. C. da Silva (Eds.), Proceedings of the 11th Space Syntax Symposium (Paper 163). Instituto Superior Técnico. https://www.researchgate. net/publication/318362684_Road_Centre_Line_ Simplification_Principles_for_Angular_Segment_ Analysis

Krivy, M., \& Kaminer, T. (2013). Introduction: The participatory turn in urbanism. Footprint: The Participatory Turn in Urbanism, 7(13), 1-6. http://dx.doi.org/ 10.7480/footprint.7.2.766

Laws, D., Scholz, R. W., Shiroyama, H., Susskind, L., Suzuki, T., \& Weber, O. (2004). Expert views on sustainability and technology implementation. The International Journal of Sustainable Development \& World Ecology, 11(3), 247-261. https://doi.org/ $10.1080 / 13504500409469829$

Loulanski, T. (2006). Revising the concept for cultural heritage: The argument for a functional approach. International Journal of Cultural Property, 13(2), 207-233. https://doi.org/10.1017/S0940739106060085

Marques, L., \& Borba, C. (2017). Co-creating the city: Digital technology and creative tourism. Tourism Management Perspectives, 24, 86-93. http://dx.doi.org/ 10.1016/j.tmp.2017.07.007

Monteiro, V., Painho, M., \& Vaz, E. (2015). Is the heritage really important? A theoretical framework for heritage reputation using citizen sensing. Habitat International, 45, 156-162. http://dx.doi.org/10.1016/ j.habitatint.2014.06.022 
Morrison, J. (2018). A definition of digital placemaking for urban regeneration. Calvium. https://calvium. com/a-definition-of-digital-placemaking-for-urbanregeneration

Morrison, J. (2020). Digital placemaking guide. Calvium. https://calvium.com/resources/digital-placemaking

O'Neill, K. (2016). Pixels and places: Designing human experience across physical and digital spaces. KO Insights.

Patil, D. R., \& Raj, M. P. (2013). Space syntax: Application to analyze mobility pattern of elderly citizens in urban public spaces [Paper presentation]. IIA NATCON 2013, Chennai, India. https://www.researchgate.net/ publication/343041393_Space_Syntax_Application_ to_analyze_mobility_pattern_of_Elderly_citizens_ in_urban_public_spaces

Pendlebury, J. (2014). Heritage and policy. In S. Watson \& E. Waterton (Eds.), The Palgrave handbook of contemporary heritage research (pp. 426-441). Palgrave Macmillan.

Pendlebury, J., \& Porfyriou, H. (2017). Heritage, urban regeneration and place-making. Journal of Urban Design, 22(4), 429-432. https://doi.org/10.1080/ 13574809.2017.1326712

Peponis, J., Bafna, S., \& Zhang, Z. (2008). The connectivity of streets: Reach and directional distance. Environment and Planning B: Urban Analytics and City Science, 35(5), 881-901. https://doi.org/10.1068/ b33088

Project for Public Spaces. (2007). What is placemaking? https://www.pps.org/article/what-is-placemaking

Project for Public Spaces. (2018). Placemaking: What if we built our cities around places? https://uploadsssl.webflow.com/5810e16fbe876cec6bcbd86e/ 5b71f88ec6f4726edfe3857d_2018\%

20placemaking\%20booklet.pdf

Ratti, C. (2004). Space syntax: Some inconsistencies. Environment and Planning B: Urban Analytics and City Science, 31(4), 487-499.

Rautenberg, M. (1998). L'émergence patrimoniale de l'ethnologie: Entre mémoire et politiques publiques [The heritage emergence of ethnology: Between memory and public policies]. In D. Poulot (Ed.), Patrimoine et modernité [Heritage and modernity] (pp. 279-291). L'Harmattan.

Riga City Council. (2020). Rīgas pilsētas lìdzdalīgās budžetēšanas projektu īstenošanas konkurss [Riga City participatory budgeting project implementation competition]. https://www.riga.Iv/lv/rigas-pilsetaslidzdaligas-budzetesanas-projektu-istenosanaskonkurss

Riga City Council. (2021). Projekti [Projects]. Balso Rīga. https://balso.riga.Iv/projekti

Roberts, P. (2000). Urban regeneration: A handbook. Evolution, definition and purpose. SAGE.

ScienceDirect. (n.d.). Virtual spaces. https://www. sciencedirect.com/topics/computer-science/virtualspaces
Sepe, M. (2015). Improving sustainable enhancement of cultural heritage: Smart placemaking for experiential paths in Pompeii. International Journal of Sustainable Development and Planning, 10(5), 713-733. https:// doi.org/10.2495/sdp-v10-n5-713-733

Stephenson, J. (2010). People and place. Planning Theory \& Practice, 11(1), 9-21. https://doi.org/10.1080/ 14649350903549878

Strydom, W., Puren, K., \& Drewes, E. (2018). Exploring theoretical trends in placemaking: Towards new perspectives in spatial planning. Journal of Place Management and Development, 11(2), 165-180, https:// doi.org/10.1108/JPMD-11-2017-0113

Sweeney, J., Mee, K., McGuirk, P., \& Ruming, K. (2018). Assembling placemaking: Making and remaking place in a regenerating city. Cultural Geographies, 25(4), 571-587. https://doi.org/10.1177/147 4474018778560

Tanrikul, A., \& Hoskara, S. (2019). A new framework for the regeneration process of Mediterranean historic city centres. Sustainability, 11(16), Article 4483. https://doi.org/10.3390/su11164483

Teller, J., \& Bond, A. (2002). Review of present European environmental policies and legislation involving cultural heritage. Environmental Impact Assessment Review, 22(6), 611-632. https://doi.org/ 10.1016/s0195-9255(02)00009-4

Toland, A., Christ, M. C., \& Worrall, J. (2020). DigitalXPlace. In D. Hes \& C. Hernandez-Santin (Eds.), Placemaking fundamentals for the built environment (pp. 253-274). Palgrave Macmillan.

Turner, A. (2004). Depthmap 4: A researcher's handbook. University College London.

Tweed, C., \& Sutherland, M. (2007). Built cultural heritage and sustainable urban development. Landscape and Urban Planning, 83(1), 62-69. https://doi.org/ 10.1016/j.landurbplan.2007.05.008

UNESCO. (2008). World heritage information kit. UNESCO World Heritage Centre. https://whc.unesco. org/document/102072

UNESCO. (2021). Historic centre of Riga. UNESCO World Heritage Centre. https://whc.unesco.org/en/list/852

Whyte, W. H. (1980). The social life of small urban spaces. Conservation Foundation.

Wyckoff, M. A. (2013). Definition of placemaking: Four different types. MSU Land Policy Institute. http://www.pznews.net/media/13f25a9fff4cf18ffff 8419ffaf2815.pdf

Yang, T., \& Hillier, B. (2007). The fuzzy boundary: The spatial definition of urban areas. In A. Kubat, O. Ertekin, Y. Guney, \& E. Eyuboglu (Eds.), Proceedings of the 6th International Space Syntax Symposium (pp. 091.01091.16). Istanbul Technical University.

Ye, Y., \& van Nes, A. (2014). Quantitative tools in urban morphology: Combining space syntax, spacematrix and mixed-use index in a GIS framework. Urban Morphology, 18(2), 97-118. https://www.researchgate. net/publication/280520750_Quantitative_tools_ 
in_urban_morphology_Combining_space_syntax_ spacematrix_and_mixed-use_index_in_a_GIS_

framework\#fullTextFileContent

Zheng, H. W., Shen, G. Q., \& Wang, H. (2014). A review of recent studies on sustainable urban renewal. Habitat

International, 41, 272-279. https://doi.org/10.1016/

j.habitatint.2013.08.006

\section{About the Authors}
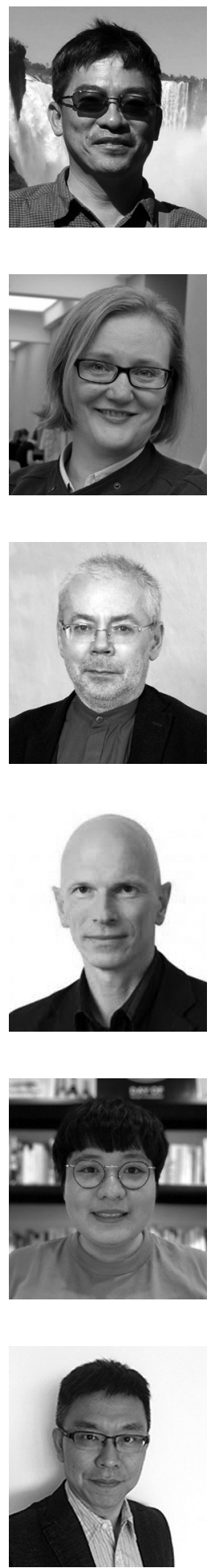

Chih-ming Shih is an architect and professor in the Department of Architecture at the National Taiwan University of Science and Technology. His research interests lie in design thinking and contemporary architecture criticism. He has published several books in Chinese and articles in Environment and Planning B: Planning and Design, Environment and Planning D: Society and Space, Journal of Architecture and Planning Studies, Journal of Visual Impairment \& Blindness, Inter-Asia Cultural Studies, and Journal of Asian Architecture \& Building Engineering.

Sandra Treija, PhD, is an architect and professor at Riga Technical University. She is also vice dean for research and director of the Centre for Urban Planning of Riga Technical University's Faculty of Architecture. Her field of research includes sustainable housing, regeneration of neighbourhoods, quality of the residential environment, and sustainable urban development. She is a coordinator of the national group of the International Organization Docomomo and MC member of the COST Action CA18137 European Middle-Class Mass Housing. She regularly speaks at international conferences and is the author and co-author of more than 50 scientific publications.

Kęstutis Zaleckis obtained the qualification of Architect at Vilnius Gediminas Technical University (VilniusTex) in 1991. In 2002, he successfully finished his PhD studies at Vytautas Magnus University and the Institute of Architecture and Construction. He is a full professor at Kaunas University of Technology's Faculty of Civil Engineering and Architecture and a senior researcher. His research focuses on the modelling of urban spatial structures in the perspective of spatial determinism by using graph models, space syntax, fractal analysis, and other complex methods.

Uǵis Bratuškins, PhD, is a Latvian architect, professor, and the present dean of the Faculty of Architecture of Riga Technical University. His research interest is focused on an up-to-date design and usage of public open space in urban areas. He is the author of more than 80 publications, a member of the editorial boards of several scientific journals, and an expert in Fondazione Romualdo Del Bianco (Florence, Italy), Latvia Science Council, and Slovenian Research Agency.

Chi-Hui Chen received her undergraduate degree in Information and Communication at Yuan Ze University and completed her MA in Architecture at the National Taiwan University of Science and Technology, where she is currently a PhD student, also in Architecture. Her research interests lie in interactive design, design thinking, social sustainability, and anthropology of architecture. She is a member of Interaction Design Association Taiwan and also holds the certificate in LEED AP BD+C and DGNB Consultant-International.

Yen-Hung Chen has been involved in teaching and research for computer-aided design and knowledge management since his early years. In his participation in a government-sponsored research project, Computer-Assisted Building Code Checking, the importance of BIM implementation for the design and construction industry was recognised. Great efforts were made to promote the use of BIM-related technology. 

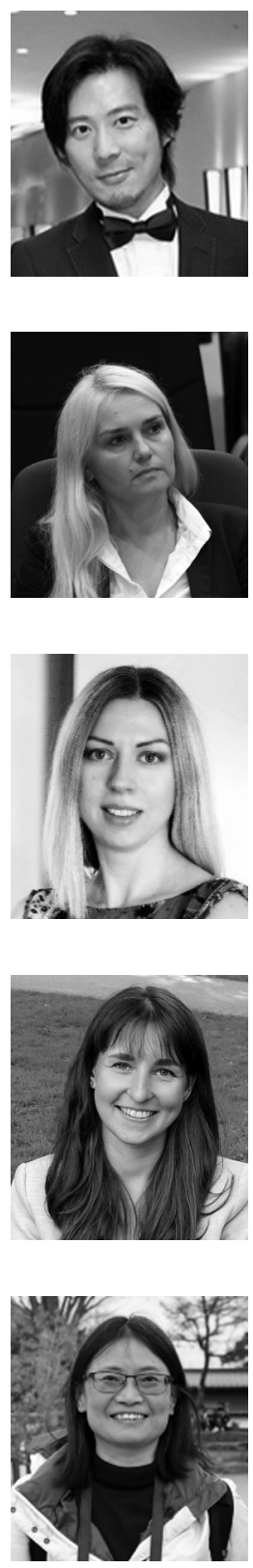

Huei-Chen Lee holds a PhD in Architecture from the National Taiwan University of Science and Technology. Her doctoral thesis focused on policy, community, and professional practice in Taiwan's historical districts. She also managed the Dadaocheng community planner workshop for the Institute for Historical Resources Management and Taipei City Urban Regeneration Office from 2015 to 2016. Her main research area is cultural heritage, conservation and regeneration in historical districts, architecture, and urban history.

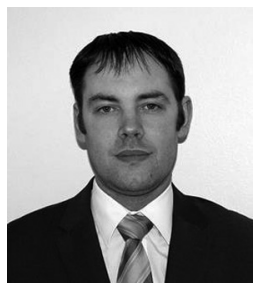

Arnis Lektauers is an associate professor at the Department of Modelling and Simulation of Riga Technical University (RTU). He obtained the degree of Doctor of Science in Engineering (Computer Science) from RTU in 2008. His research focuses on the development of high-performance computingbased interactive hybrid modelling and simulation methods and algorithms applied to complex systems analysis in the area of industrial, economic, ecological, and sustainable development. He is co-author of more than 45 articles in scientific journals and conference proceedings.

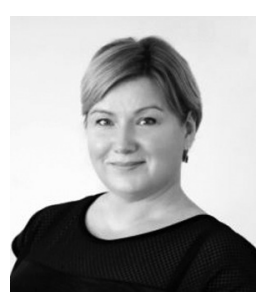

Aušra Mlinkauskienė is an assistant professor in the Faculty of Civil Engineering and Architecture at the Kaunas University of Technology. She holds a PhD in Environmental Engineering and Land Management from Kaunas University of Technology. Her research focuses on heritage protection and urban spatial planning, management, and protection. She is also responsible for the identification of valuable properties of heritage objects in the regional heritage assessment council and is a member of the research group Cultural and Spatial Environment. 